GLOBAL JOURNAL OF AGRICULTURAL SCIENCES VOL 9, NO. 1, 2010: 37-40

COPYRIGHT@ BACHUDO SCIENCE CO. LTD PRINTED IN NIGERIA. ISSN 1596-2903

www.globaljournalseries.com; Email: info@globaljournalseries.com

\title{
FERTILIZER-MANURE SUBSTITUTION AMONG ARABLE CROP FARMERS IN AKWA IBOM STATE: EMPIRICAL EVIDENCE.
}

\author{
S. B. AKPAN, E. J. UDOH and E. A. AYA
}

(Received 3, August 2009; Revision Accepted 10, June 2010)

\begin{abstract}
The study estimated the constant elasticity of substitution of fertilizer for manure in arable crop production in Akwa Ibom State. The approximation of the generalized constant elasticity of substitution (CES) model using Taylor's expansion series yielded a linear equation that was estimated using OLS method. The CES parameters were estimated through a system of coefficients relationship and were later used to calculate the constant elasticity of substitution for each crop enterprise. Empirical results revealed that, waterleaf has constant elasticity of substitution less than unity: while pumpkin and maize had constant elasticity of substitution greater than unity. Increased supply of fertiliser and repackage extension services were recommended as these would help to increase fertiliser use as well as growth rate of crops in the state.
\end{abstract}

KEY WORDS: Arable Crop, Elasticity, Fertiliser, Manure, Substitution

\section{INTRODUCTION}

Arable crop production is one of the agricultural subsectors that have thrived over the years in Akwa-lbom state. Its popularity can be linked to various factors including low cost per unit of resources used in production, short gestation period and quick returns on invested fund compared to other sub-sectors of agriculture (Udoh 2005 and Umoren, 1998). In the past years, arable crop production in Akwa-lbom state was practiced using traditional shifting cultivation system that was associated with land fallowing. In the system, farmers allowed soil to rest or fallow (at least for the period of 7 years as was practiced in the state) adequately in order to ensure optimum regeneration of organic biomass that would promote sustainable soil fertility. Due to population pressure and rapid urbanization, the former cropping system was no longer sustainable in term of enhancing soil fertility and increased yield of crops. Hence continuous cropping without appropriate soil management leads to deterioration in soil physical, chemical and biological properties (Chinedu et al., 2002). Consequently, declining yields, low resource productivity among other resource problems would follow. The failure of the previous cropping system and prevailing problems prompted farmers to adopt alternative technologies (that is the use of organic manure and inorganic fertilizer) to improve soil fertility and enhance crop yield (Reijnties et al. 1992 and Adepetu 1997).

Many researchers have reported the use of organic manure (animal dung, poultry droppings, farm yard manures and compost manures) as soil enhancing

S. B. Akpan, Department of Agricultural Economics, Michae

E. J. Udoh, Department of Agricultural Economics, Michael O

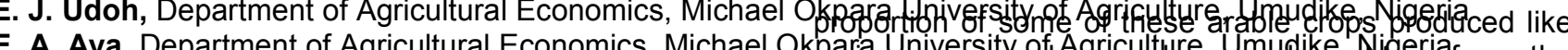
E. A. Aya, Department of Agricultural Economics, Michael Okparizenniversityof Agriculthbre Upeudikoughigeria from the

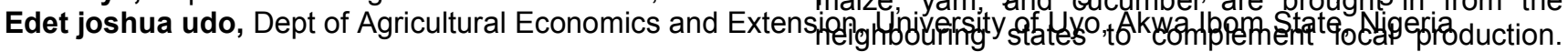

materials to increase arable crop productivity in the south - south and south east Nigeria (Beckman 1973; Udoh et al. 2007; Udoh 1993; Chinedu et al. 2002; and Olayinka et al.1998). Also, significant impact of fertilizer usage by arable crop farmers in the southern region of the country had been reported by numerous researchers (Udoh et al. 2007; Osuhor et al. 2002; and Carsky et al. 1999).

Fertilizer and manures are also production inputs that have economic value and are thus limited in supply (Udoh 2005 and Udoh et al. 2001). The quantities of fertilizers and manures available to farmers are constrained by fluctuation in prices of these inputs. Therefore, efficient combination or substitution of these inputs (for each other) is an important part of agricultural sustainability in the state. One way subsistence farmers can achieve agricultural sustainability in their production is to rise the productivity of their farms by improving resource substitution within the limits of existing resource base and technology (Udoh 2005 and Harwood 1987). The existence of budgetary constraint in acquiring fertilizer and manure by the farmers in the state created the need for a plan for the substitution between the two inputs to help maximize farmer's income. The prevalence of land fragmentation in the rural areas of the state and low growth rate in crop outputs also necessitated the argument for efficient fertilizer-manure substitution among the arable crop farmers in the state.

Despite the early adoption of these technologies by arable crop farmers, the crop outputs have not shown an encouraging growth rate (CBN, 2003). Large
With rapid population increase in the state, there is an overwhelming need for reassessment of the fertilizer policies in the state. Therefore, given the present situation of low growth rate of arable crop outputs, rapid population growth and highly publicized fertilizer subsidy 
programme in the state: the necessary question is, why are arable crop farmers in the Akwa lbom state despite the incentive from government unable to produce enough food to feed the citizens and rather depend on food items from the neighbouring states? To answer this question, we assumed that crop farmers in Akwa Ibom state do not have enough quantity of fertiliser to augment efficiently the depleted soil and decided to substitute fertilizer for more affordable but poorly composed organic manure. In addition, we also assumed that, the substitution of fertiliser for manure in the state by arable crop farmers assumed fairly stable ratio and that other production factors are not constrained to the production of the crop enterprises.

The study specifically focused on the determination of the assumed constant elasticity of substitution of fertiliser for manure by arable farmers in Akwa lbom state. The results will reveal the approximate values for constant elasticity of substitution of the two inputs in each of the crop enterprises used in the analysis. In addition, the results will also unveil the need for government and private intervention in the provision of both inputs to farmers and as a basis for formulating future sustainable fertiliser policy in Akwa Ibom state.

\section{MATERIALS AND METHODS}

The study was conducted in Akwa Ibom state. Three local government areas were randomly selected for data collection. The local government areas were Itu, Uyo and Ibesikpo. Twenty farmers from each of the three local government areas, producing each of the selected arable crop enterprises were randomly picked from areas of intense cultivation. A total of sixty farmers were used for each of the crop enterprise. Baseline information on socio economic characteristics, inputs use and outputs as well as unit prices were collected. The crop enterprises were waterleaf, pumpkin (Telfairia occidentalis), and maize.

\section{EMPIRICAL MODEL}

The generalized constant elasticity of substitution (CES) was specified. The variables were normalized by output price.

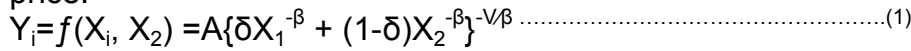

Where,

$A=$ efficiency parameter $(A>0)$

$\delta=$ distribution parameter $(0<\delta<1)$

$\beta=$ substitution parameter $(\beta \geq-1)$

$Y_{i}=$ normalized output of $i_{\text {th }}$ crop in $\mathrm{Kg}$

$\mathrm{X}_{1}=$ normalized quantity of fertilizer used in $\mathrm{i}_{\text {th }}$ crop

$\mathrm{X}_{2}=$ normalized quantity of manure used in $\mathrm{i}_{\mathrm{th}}$ crop

$\mathrm{V}=$ return to scale parameter $(\mathrm{V}>0)$

Kmenta (1967) states that in the above CES function, when $\beta$ is in the neighbourhood of zero or when the elasticity of substitution $\sigma$ is in the neighbourhood of unity, that the CES function can be approximated with a Taylor expansion series around $\beta=0$. Then equation (1) becomes:

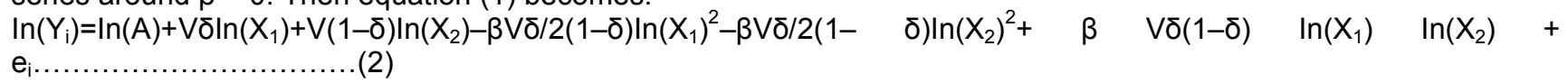

Further simplification yields equation (3)

$\ln \left(Y_{i}\right)=\ln (A)+V \delta \ln \left(X_{1}\right)+V(1-\delta) \ln \left(X_{2}\right)-\beta V \delta / 2(1-\delta)\left\{\ln \left(X_{1}\right)-\ln \left(X_{2}\right)\right\}^{2}$

$+e_{i}$

Equation (3) is recognized as a linear equation by which ordinary least squares estimation can be applied. The new form of equation (3) now becomes:

$\ln \left(Y_{i}\right)=b o+b_{1} \ln \left(X_{1}\right)+b_{2} \ln \left(X_{2}\right)+b_{3} \ln \left\{\ln \left(X_{1}\right)-\ln \left(X_{2}\right)\right\}^{2}+e$

The implication of the transformation is that, if fertilizer and manure technology is believed to have a constant elasticity of substitution in the production of the various crop enterprises and have this elasticity of substitution in the neighbourhood of unity: then the input and the output values observed for the production of these crops may be fitted to equation (4). It then follows that the restriction stated below must be used to test whether the estimated function does in fact approximate the CES function in equation (1) and thus estimate the CES parameters $A, \delta, \beta$ and $V$.

$A=$ antilog of bo, $V=b_{1}+b_{2}, \quad \delta=b_{1} /\left(b_{1}+b_{2}\right)$, and $\beta=-2 b_{3}\left(b_{1}+b_{2}\right) / b_{1} b_{2}$

$\sigma=1 /(1+\beta)$

Where, $\sigma$ is the constant elasticity of substitution of fertilizer for manure in the production of each crop output. Given the above definition of $\sigma$, the following relationships between $\sigma$ and $\beta$ hold (Bruno et al, 2005).

$>\quad \sigma=\infty$ then $(\beta=-1)$ : CES takes the linear form and the inputs are perfect substitutes so that the farmers have no special preference for any of the inputs.

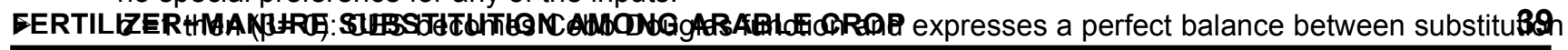
and complementary effects. That is unity elasticity of substitution between the two inputs.

$>\quad \sigma<1$ then $(\beta>0)$ : CES function becomes production function with significant complementarity effects between inputs.

$>\quad \sigma>1$ then $(\beta<0)$ : CES function shows inputs that are partial substitutes.

\section{RESULTS AND DISCUSSION}

Table 1: Result of estimating equation (4) for specified crop enterprises and the corresponding approximate of CES parameters including elasticity of substitution of fertilizer for manure for each crop enterprise.

\begin{tabular}{|l|l|l|c|}
\hline Variable \& Parameter & Waterleaf & Pumpkin & Maize \\
\hline
\end{tabular}




\begin{tabular}{|c|c|c|c|}
\hline$b_{0}$ & $\begin{array}{c}3.16^{\star * *} \\
(4.48)\end{array}$ & $\begin{array}{l}2.27^{* *} \\
(2.18)\end{array}$ & $\begin{array}{c}3.76^{\star * \star} \\
(2.38)\end{array}$ \\
\hline$b_{1}$ & 0.30 & $0.25^{\star *}$ & $0.60^{\star *}$ \\
\hline$b_{2}$ & $1.10^{\star \star \star}$ & 0.15 & 0.75 \\
\hline & $(3.32)$ & $(0.40)$ & (1.53) \\
\hline$b_{3}$ & $-0.10^{*}$ & $0.003^{* *}$ & $0.08^{* *}$ \\
\hline $\mathrm{R}^{2}$ & $\begin{array}{c}(-1.95) \\
0.52\end{array}$ & $\begin{array}{c}(2.00) \\
0.33\end{array}$ & $\begin{array}{c}(2.14) \\
0.44\end{array}$ \\
\hline F-cal & $8.45^{\star \star *}$ & $1.89^{*}$ & $4.65^{\star * *}$ \\
\hline \multicolumn{4}{|l|}{ CES } \\
\hline A & 23.6 & 9.69 & 42.95 \\
\hline V & 1.39 & 0.39 & 1.35 \\
\hline$\delta$ & 0.213 & 0.63 & 0.45 \\
\hline$\beta$ & 0.836 & -0.07 & -0.45 \\
\hline$\sigma$ & 0.545 & 1.070 & 1.820 \\
\hline
\end{tabular}

Note: Figures in bracket are t- values, while *, ${ }^{* *}$ and *** represent $10 \%, 5 \%$ and $1 \%$ significance levels respectively. All other variables are as defined in equation (1) and (4).

The first part of the result in Table 1 shows the estimated equation (4) for the specified crop enterprises. The result reveals F-value of (8.45) for waterleaf, (1.89) for pumpkin and (4.65) for maize significant at $1 \%, 10 \%$ and $1 \%$ respectively. This indicates a good fit for the specified double log model in equation (4) for each crop enterprise. The value of $R^{2}$ for each crop enterprise shows that considerable variation in output was caused by the used of fertilizer and manure. The second part shows the approximated CES parameters: each parameter satisfies the condition specified in equation (1). This confirms the fact that CES production function could be fitted to each of the crop enterprise specified using fertilizer and manure as production inputs. The last part reveals the constant elasticity of substitution of fertilizer for manure in each of the crop enterprise used in the analysis. The constant elasticity of substitution of fertilizer for manure was estimated following equation (5).

The result reveals that in the production of waterleaf, the constant elasticity of substitution (0.545), of fertilizer for manure is less than unity. This implies that fertilizer and manure inputs in the estimated CES production function for waterleaf has a significant complementarity effect between them. This indicates that, waterleaf farmers in Akwa Ibom State use fertilizer to complement manures in enhancing soil fertility. Farmers that cultivate the crop used more of manure than fertilizer. From the result, it could be asserted that waterleaf production in the state is organized in small scale basis with minimal financial investment especially in fertilizer procurement and usage. The possible reason could be the insufficient quantity of fertilizer which could likely be attributed to high purchasing cost.

The constant elasticity of substitution of fertilizer for manure in the production of pumpkin (1.070) and maize (1.82) is greater than one. The estimated CES production functions for the crop enterprises showed that fertilizer and manure are partial substitutes. The results imply that, the quantity of fertilizer used in place of manures by pumpkin and maize farmers in Akwa
Ibom State exhibits insignificant variations. The estimated index of CES for the two inputs reveals that more of fertilizer is substituted for manures, but at insignificant quantity levels. The results also show that pumpkin and maize farmers in the state are more conscious of the importance of both inputs and hence tend to utilize them rationally. This connotes that, the crops are market oriented and thus farmers have to invest more money in purchasing fertilizer and manures, but giving more preference to fertilizer in order to increase yield.

\section{CONCLUSION AND POLICY IMPLICATION OF RESULTS}

The study modelled the constant elasticity of substitution of fertilizer for manure in arable crop production in Akwa lbom state. Constant elasticity of substitution of fertilizer for manure was assumed following low production growth rate of crop output in the ste manifested by influx of some of food items into the

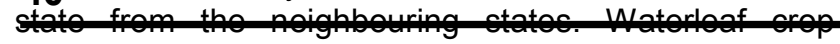
enterprise has constant elasticity of substitution of fertilizer for manure less than one: pumpkin and maize enterprises had CES greater than unity. To increase arable crop output, the following policy recommendations are advocated.

* Farmers with constant elasticity of substitution less than unity have more access to organic manures than fertilizer. As such, state extension programme should be repackaged to address the problem of poor fertilizer adoption by these farmers, while concerted effort should be made by the state ministry of agriculture to increase fertilizer supply at a subsidized rate to these farmers.

* Farmers with constant elasticity of substitution greater than unity, have access to both fertilizer and organic manure; but higher preference to fertilizer procurement. This means that, these crops are market oriented crops, and farmers tend to be rational in resource allocation. As such, government should provide incentive to such farmers while private investment should be 
encourage in these crop enterprises, as their revenue could adequately offset the fertilizer cost.

\section{REFERENCES}

Adepetu, J. A., 1997. Soil and Nigeria food security. Inaugural Lecture Series 119, Obafemi Awolowo University, Ile-Ife, Nigeria. Pp.19.

Beckman, E. O., 1973. Organic fertilization, Vegetable farming luxury or necessity. Tech. communication ISHA, 29 - 247.

Bruno C., M. Benton, P. Sriran and V. Kasturi., 2005. Market equilibrium for CES exchange economies: Existence, multiplicity and computation. Paper presented at a DIMACS workshop on large scale games Chicago.

Carsky R. J., Iwuafor Eno., 1999. Contribution of soil fertility research and maintenance to improve maize production and productivity in subSaharan Africa In ed B. Badu-Apraku, MAB Fakorede, M Ouedraogo, F. M. Quin Strategy
Reijnties C, Hoverkork B, Water-Bayer A., 1992. An Introduction to Low-External-Input and Sustainable Agriculture. John Wiley \& Sons. London p. 340.

Udoh, E. J., 2005. Technical inefficiency in vegetable farms of humid Region. An analysis of dry season farming by urban women in South-South zone, Nigeria. J. agric. \& social Sci., 1: 80-85.

Udoh, E. J., 1993. Economics of waterleaf production in Calabar municipality Cross River State, university of Calabar, unpublished B.Sc project.

Udoh, E. J. and J. O. Akintola., 2001. Technical efficiency of crop farms in the south eastern region of Nigeria, Nigerian journal of economics and social studies, 42: 93-104.

Umoren, E. J., 1998. The marketing of perishable farm produce in Akwa Ibom State. Unpublished project. for Sustainable Maize Production In West and Central Africa. Proceedings of Regional Maize Workshop 21-25 April, 1997. IITA-Cotonou, Benin Republic. Pp. 3-20.

CBN, (2003). Statistical bulletin (December).

Chinedu, N. and O. Adeolu A., 2002. Organic manure used among smallholders in the rainforest of southeast Nigeria. Deytscher witzenhausen.

Harwood, R. R., 1987. Low Input Technologies For sustainable Agricultural System. Westview press Boulder, Col. London.

Kmenta, J., 1967. On Estimation of the CES Production Function. International Economic Review 8:18089.

Olayinka A, Adetunji A, Adebayo A., 1998. Effect of organic amendments on nodulation and nitrogen fixation of cowpea. J. Plant Nutr. 21(11): 24552464.

Osuhor, C. U., J. P. Alawa and G. N. Akpa., 2002. Manure production by goats' grazing native pasture in Nigeria. Tropical grassland vol. 36. Pp 123-125. 